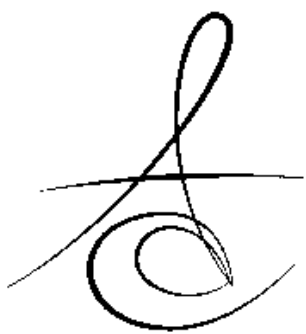

\title{
KIBT İLE TESADÜFEN BULUNAN PARSİYEL EMPTY SELLA TANISI: İKI VAKA RAPORU
}

\section{INCIDENTAL DIAGNOSIS OF PARTIAL EMPTY SELLA ON CBCT: TWO CASE REPORTS ${ }^{*}$}

Doç. Dr. Hakan EREN ${ }^{*}$

Prof. Dr. Kaan ORHAN*

Doç. Dr. Mehmet Eray KOLSUZ*

Makale Kodu/Article code: 3079

Makale Gönderilme tarihi: 12.12 .2017

Kabul Tarihi: 19.04.2018

\section{ABSTRACT}

Empty sella syndrome is defined as a herniation of the subarachnoid space within sella, hence, flattening of the pituitary gland. Most of the empty sella cases are found incidentally which this syndrome can be easily missed during maxillofacial radiological examinations. The aim of this paper is to describe two cases of partial empty sella and discuss the differential diagnosis for this condition.

Both patients administered to our clinic with pain in the forehead and maxilla. In addition to clinical examination two patients (37 year old male, 70 year old female) were imaged using panoramic radiography, cone beam computed tomography and magnetic resonance imaging. Panoramic radiographies showed no findings in terms of empty sella. However, in CBCT imaging, both patients showed an expansion in the sella turcica and protrusion into sphenoid sinus. These were more precisely located using 3D CT reconstructions. MR imaging showed intermediant signal on T1-weighted images and high signal on T2weighted images. MRI findings showed the partial anterior prolapsus of pituitary gland with cerebrospinal fluid leak in posterior border of sella turcica. According to MRI findings, definitive diagnosis was partial empty sella syndrome.

Maxillofacial radiologists should be aware of this kind of abnormalities while reporting the entire FOV.

Keywords: Empty Sella Syndrome, CBCT, MRI, sella turcica, pituitary gland

\section{öz}

Empty sella sendromu, subaraknoid bölgenin sella içerisine herniyasyonu bundan dolayı da hipofiz bezinin düzleşmesi olarak tanımlanmıştır. Bir çok empty sella vakası tesadüfen tespit edildiği için bu sendrom maksillofasiyal radyolojik inceleme sırasında kolaylıkla gözden kaçabilir. Bu makalenin amacı iki parsiyel empty sella vakasını sunmak ve bu durum ile ilgili ayırıcı tanıları tartışmaktır.

Her iki hasta da maksilla ve alın bölgesinde ağrı ile kliniğimize başvurdu. Klinik muayeneye ek olarak her iki hastadan da (37 yaş erkek, 70 yaş kadın) panoramik radyograf, konik ışınlı bilgisayarlı tomografi ve manyetik rezonans görüntüleme ile görüntüler alındı. Panoramik radyografide empty sellaya ilişkin herhangi bir bulguya rastlanmadı. Ancak, KIBT görüntülerinde her iki hastada da sella tursikada ekspansiyon ve sfenoid sinüs içerisine protrüzyon görüldü. Bu bulgular 3 boyutlu rekonstrüksiyon görüntülerinde tam olarak lokalize edildi. Manyetik rezonans görüntülemede T1 ağırlıklı görüntülerde orta düzeyde sinyal ve T2 ağırlıklı görüntülerde ise yüksek sinyal alındı. MRG bulguları sella tursikanın arka sınırında serebrospinal sıvı sızıntısı ile birlikte hipofiz bezinin parsiyel anterior prolapsusu olduğunu gösterdi. MRG bulguları ile parsiyel empty sella kesin tanısı kondu.

Maksillofasiyal radyologlar görüntüleme alanına giren tüm yapıları rapor ederken bu tip patolojilere de dikkat etmelidirler.

Anahtar Kelimeler: Empty sella sendromu, KIBT, MRG, sella tursika, hipofiz bezi

\footnotetext{
*Ankara Üniversitesi, Diş Hekimliği Fakültesi, Ağız Diş Çene Radyolojisi AD, Ankara.

${ }^{*} \mathrm{Bu}$ çalıssma 20th international congress of dento-maxillo-facial radiology kongresi

26-29 Ağustos 2015 tarihleri arasında Santiago şili'de poster sunumu olarak tebliğ edilmiştir.
} 


\section{INTRODUCTION}

In the pituitary region, several types of sellar suprasellar lesions may present. ${ }^{1}$ Empty sella syndrome is defined as a herniation of the subarachnoid space within sella, hence, flattening of the pituitary gland. ${ }^{2,3}$ It is first explained by Busch et al. on autopsies in $1951 .^{4}$ Most of the empty sella cases are found incidentally. In addition, 3D imaging methods including MRI and CT taken for other reasons are primary diagnostic tools. In recent years, the use of $\mathrm{CBCT}$ imaging method in viewing maxillofacial region in dentistry is highly increased. Most of the 3D dental images, especially including maxilla, include sella region. However, dental radiologists are not aware of area outside the maxillofacial region. Therefore, empty sella syndrome can be easily missed during dental radiological examinations.

In this case report, an incidentally found two partial empty sella syndromes which were very firstly diagnosed on CBCT during a post-operative examination of reconstruction surgery planning on maxillofacial region is reported with the differential diagnosis for this condition.

\section{CASE REPORT 1}

A 37 year-old male patient was admitted to our hospital for detailed CBCT examination of reconstruction surgery planning on maxillofacial region. In the medical history; patient had been previously operated for osteosarcoma 3 years ago. As well as he had a 2 years of moderately chronic temporofrontal headaches. Additionally, He had hypertension and diabetes mellitus in his medical history. CBCT was taken in skull mode (230x260 mm FOV). CBCT images showed a large defect area in the maxillar region caused by surgical operation without further pathology in the region. However, partial prolapsus was detected in the anterior border of sella turcica suggesting initial diagnosis of partial empty sella syndrome (Figure 1). Patient was referred to MRI for detailed examination. MRI revealed a maximum $3 \mathrm{~mm}$ thickness of the middle and anterior part of hypopysis gland which is consistent with a partial empty sella. MR imaging showed isointense signal on T1- weighted images (Figure 2) and intermediant to high signal on T2weighted images (Figure 3) relate to Cereprospinal fluid leak (CSF). So, these findings showed the partial anterior prolapsus of pituitary gland with cerebrospinal fluid leak in posterior border of sella turcica. According to MRI findings, definitive diagnosis was partial empty sella syndrome. It was thought that patient's chronic headaches might be due to this finding, so, patient was referred to neurology and endocrinology clinic for further examinations.

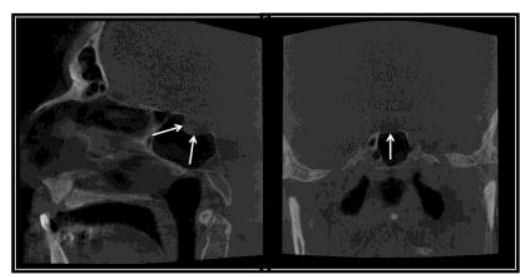

Figure 1. Sagittal and coronal CBCT images are showing partial prolapsus in the anterior border of the cella (arrows).

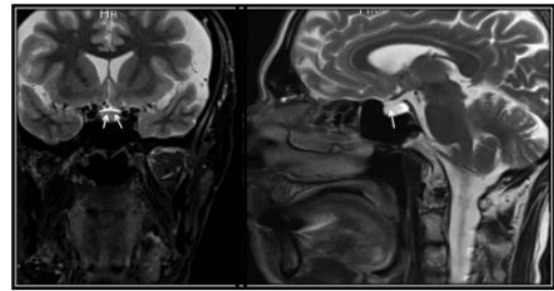

Figure 2. T-1 weighted MR images showing isointense signal intensity with CSF leak in the posterior part of the cella (arrows).

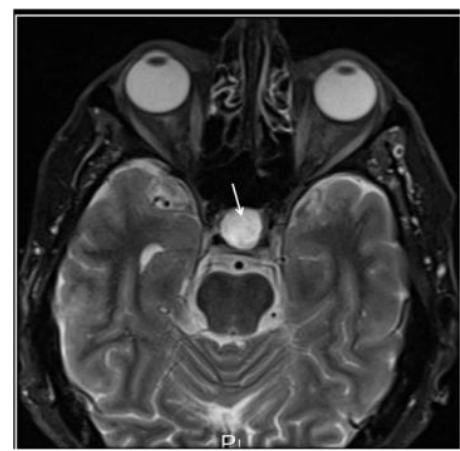

Figure 3. T-2 weighted MR images showing intermediant to high signal intensity related to CSF leak (arrows).

\section{CASE REPORT 2}

A 70 year-old female patient was admitted to our hospital for pain on the maxilla and left TMJ area. According to anamnesis, patient had these pains for the last 2 years. The pain had been progressing especially at nighttimes. She had no history of trauma or steroid injection to or any other operation to jaws or TMJ area. Her medical history were not remarkable 
but she had hypertension and diabetes mellitus in his medical history. A positive decision was made for $\mathrm{CBCT}$ in order to evaluate the region. $\mathrm{CBCT}$ was taken in skull mode $(230 \times 260 \mathrm{~mm}$ FOV). CBCT images showed a partial prolapsus in the anterior border of sella turcica suggesting initial diagnosis of partial empty sella syndrome (Figure 4). Patient was referred to MRI for detailed examination. MRI revealed prolapsus in the middle and anterior part of pituitary gland which is consistent with a partial empty cella. MR imaging showed intermediant signal on T1weighted images and high signal on T2-weighted images which was monitored as in the first case (Figure 5-6). The patient was referred to neurology clinic for further examinations.

Both patients were diagnosed as 'partial empty cella' after consultations. Apporiate treatment modlietis were applied to patients by neurology clinic.

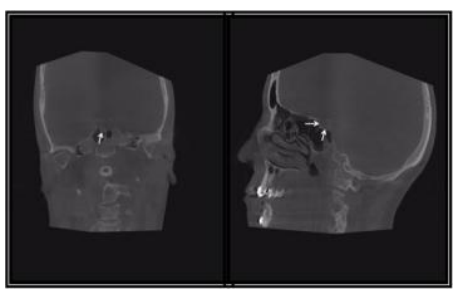

Figure 4. Coronal and sagittal CBCT images are showing a partial prolapsus in the anterior border of sella turcica (arrows).

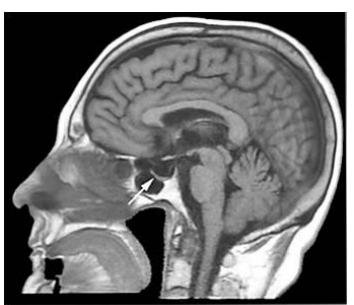

Figure 5. Sagital T-1 weighted MR images are showing intermediate signal of the gland displaced to sphenoid sinüs (arrow).

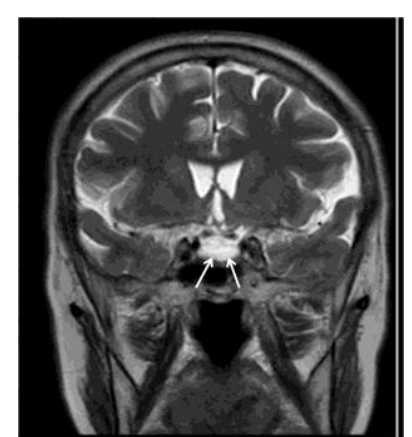

Figure 6. T-2 weighted MR image is showing high signal intensity for empty cella (arrows).

\section{DISCUSSION}

We present two cases of partial empty sella syndrome which were very first prediagnosed by CBCT examination. According to our research, there is not any other case in the literature prediagnosed by CBCT images. So, these are the first cases initially diagnosed by $\mathrm{CBCT}$.

There are two types of empty sella syndrome; primary and secondary. Primary empty sella defined as extension of subarachnoid space toward the intrasellar region. ${ }^{5}$ As a result of this event, pituitary gland becomes flattened and sella region looks like empty on MRI. ${ }^{6}$ If an empty sella occurs as a result of pituitary surgery or radiation therapy, it is called secondary empty sella. In this case, our patient had a previous maxillofacial region surgery and radiotherapy for osteosarcoma. MRI findings showed a partial anintense space in the intrasellar region with hyperintense cerebrospinal fluid leak in the posterior. Thus, the present cases can be identified as secondary partial empty sella syndrome.

It has been previously reported in postmortem studies that about $20 \%$ of the population had evidence of empty sella. ${ }^{7}$ Another study showed that $5.5 \%-23 \%$ of autopsies had empty sella. ${ }^{3}$ Although it is a common disorder, most of the empty sella cases are found incidentally. ${ }^{8}$ It might be because, most of the cases stay with slight symptoms or without any symptoms, as well as, $20-50 \%$ of the patients have endocrinologic dysfunction. ${ }^{9}$ Cone beam computed tomography is a frequently used dental imaging method in the last 20 years. ${ }^{10}$ In addition, sella region has a close adjacency with maxillofacial region and it commonly enters into FOV area. But there is not any case of empty sella which is diagnosed by dental radiologists or by $\mathrm{CBCT}$ images in the literature. So, the dental examiner or radiologist should be aware of possible findings of empty sella syndrome in sella region, because of relationship between sella turcica and maxillofacial components.

There are some studies that have described association between empty sella syndrome and endocrinologic dysfunctions like hyperprolactinemia, hypopituitarism or hypogonadism. ${ }^{11-13}$ But, these disorders are mostly associated with primary empty sella. In the present case, it was thought that empty sella has been developed secondary to radiotherapy.

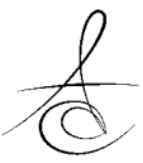


Thus, the first patient's need of further endocrinologic examinations for revealing of potential findings due to empty sella syndrome was considered and the patient was reffered to endocrinology clinic.

Some of the articles have been associated the empty sella syndrome to clinical disturbances including headaches, papilledema and visual reduction, pituitary dysfunction and sometimes rhinorrhea. ${ }^{14,15}$ The present patients had complaints regarding chronic temporofrontal headaches which gives rise to thought that might be associated with empty sella syndrome. Therefore, second patient was also referred to neurology clinic for further examinations and the neurological examination has been positively supported this idea. But, patient could not be followed up after consultation.

In summary, we firstly present two cases of partial empty sella syndrome which were initially diagnosed by $\mathrm{CBCT}$ findings. But, definitive diagnosis must be made by MRI. Consequently, dental radiologists should be aware and look at sella region for a possible finding of empty sella syndrome, if a possible clinical finding exists suggesting that patient has empty sella syndrome.

Hakan EREN: ORCID ID: 0000-0001-9006-6836

Mehmet Eray KOLSUZ: ORCID ID: 0000-0001-8872-1897

Kaan ORHAN: ORCID ID: 0000-0001-6768-0176

\section{REFERENCES}

1. Sümbüllü MA, Çakur B Çağlayan F. Prevalence Of Pituitary Calcifications Using Cone Beam Computed Tomography In Turkish Subpopulation. Atatürk Üniv Diş Hek Fak Derg 2013;21:289-92.

2. Bergland RM, Ray BS, Torack RM. Anatomical variations in the pituitary gland and adjacent structures in 225 human autopsy cases. J Neurosurg 1968;28:93-9.

3. McLachlan MS, Williams ED, Fortt RW, Doyle FH. Estimation of pituitary gland dimensions from radiographs of the sella turcica. A post mortem study. Br J Radiol 1968;41:323-30.

4. Busch W. Morphology of sella turcica and its relation to the pituitary gland. Virchows Arch 1951 Sep; 320:437-58.

5. Abboud CF. Anterior pituitary failure. In: Melmed $S$ (ed) The pituitary. Cambridge; Blackwell Sci 1995; p. 394-95.
6. Aruna P, Sowjanya B, Reddy PA, Krishnamma M, Naidu JN. Partial empty sella syndrome: a case report and review. Indian J Clin Biochem 2014; 29:253-6.

7. Robinson DB and Michaels RD. Empty sella resulting from the spontaneous resolution of a pituitary macroadenoma. Arch Intern Med 1992; 152:1920-3.

8. Komada $H$, Yamamoto $M$, Okubo $S$, Nagai $K$, Iida K, Nakamura T, Hirota Y, Sakaguchi K, Kasuga M, Takahashi $Y$. A case of hypothalamic panhypopituitarism with empty sella syndrome: case report and review of the literature. Endocr J 2009;56:585-9.

9. Kaufman B, Chamberlin WB Jr. The ubiquitous "empty" sella turcica. Acta Radiol Diagn (Stockh) 1972;13:413-25.

10. White, SC, Pharoah, MJ. The Evolution and Application of Dental Maxillofacial Imaging Modalities. Dent Clin North Am 2008; 52:689-705.

11. Arai H. Empty sella syndrome. Nihon Rinsho 2006 May 28;Suppl 1:212-6.

12. De Marinis L, Bonadonna S, Bianchi A, Maira G, Giustina A. Primary empty sella. J Clin Endocrinol Metab. 2005;90:5471-7.

13. Bianconcini $G$, Bragagni $G$ and Bianconcini $M$. [Primary empty sella syndrome. Observations on 71 cases]. Recenti Prog Med 1999;90:73-80.

14. Greenberg MS. Handbook of Neurosurgery. $7^{\text {th }}$ ed. Stuttgart; Thieme Publishers.: 2010.

15. Maira G, Anile C, Mangiola A. Primary empty sella syndrome in a series of 142 patients. J Neurosurg. 2005;103:831-6.

\author{
Yazışma Adresi \\ Dr.Dt. Hakan Eren \\ Çukurambar Mah. 1431. Cad. No:17/24 \\ Çankaya/Ankara \\ Tel: 05068691611 \\ email: dthakaneren@yahoo.com.tr
}

